\title{
Distinct Thermodynamics for the Formation and Cleavage of N-H bonds in Aniline and Ammonia. Directly-Observed Reductive Elimination of Ammonia from an Isolated Amido Hydride Complex
}

\author{
Mira Kanzelberger, Xiawei Zhang, Thomas J. Emge, Alan S. Goldman,* \\ Jing Zhao, Christopher Incarvito, and John F. Hartwig* \\ Department of Chemistry, Rutgers University 610 Taylor Road, Piscataway, NJ 08854- \\ 8087 and Department of Chemistry, Yale University, P.O. Box 208107, New Haven, \\ Connecticut 06520-8107
}

\section{Supporting Information:}

General Methods. Unless otherwise noted, all reactions, recrystallizations and routine manipulations were performed at ambient temperature in an argon-filled glovebox, or by using standard Schlenk techniques. Kinetic experiments were carried out in screw-capped NMR tubes in deuterated solvents and were monitored by ${ }^{1} \mathrm{H}$ and ${ }^{31} \mathrm{P}$ NMR spectroscopy. $n$-Pentane (tech grade) was distilled under nitrogen from purple sodium/benzophenone ketyl made soluble by addition of tetraglyme to the still and was degassed prior to use. Benzene, toluene, tetrahydrofuran (THF), $p$-xylene and diethyl ether were distilled from sodium/benzophenone ketyl under nitrogen. Deuterated solvents for use in NMR experiments were dried as their protiated analogs, but were vacuum transferred from the drying agent. (PCP) $\mathrm{IrH}_{2}{ }^{1}$ and (PCP) $\mathrm{IrHCl}^{2}$ were prepared according to published methods. All other chemicals were used as received from commercial suppliers.

${ }^{1} \mathrm{H}$ and ${ }^{13} \mathrm{C}\left\{{ }^{1} \mathrm{H}\right\}$ NMR spectra were obtained on a 300-MHz, Varian Mercury 300, Bruker DPX 400- or 500-MHz Fourier Transform spectrometers. ${ }^{31} \mathrm{P}\left\{{ }^{1} \mathrm{H}\right\}$ and ${ }^{2} \mathrm{H}$ NMR spectra were obtained on a GE $\square 300$ or GE $\square 500$ Fourier Transform spectrometer. ${ }^{1} \mathrm{H},{ }^{13} \mathrm{C}$ and ${ }^{2} \mathrm{H}$ NMR chemical shifts are reported in ppm downfield from tetramethylsilane and were referenced to residual protiated $\left({ }^{1} \mathrm{H}\right)$ or deuterated solvent $\left({ }^{13} \mathrm{C}\right)$ or natural abundance deuterated solvent $\left({ }^{2} \mathrm{H}\right) .{ }^{31} \mathrm{P}$ NMR chemical shifts were referenced to $85 \% \mathrm{H}_{3} \mathrm{PO}_{4}$. The ${ }^{15} \mathrm{~N}$ shifts are referenced to the ammonium ion of ${ }^{15} \mathrm{~N}$-enriched ammonium chloride $(5 \mathrm{M}$ in $2 \mathrm{~N}-\mathrm{HCl}$ ). Elemental analyses were performed by Robertson Microlit Laboratories, Inc., Madison, NJ 07940. Infrared (IR) spectra were recorded on a MIDAC Fourier Transform spectrometer or ATI Mattson Genesis Series FTIR ${ }^{\mathrm{TM}}$ in pentane solutions.

Dodecahydrotriphenylene was employed as an internal standard when yields were determined by NMR spectroscopy.

(PCP)IrH(NHPh) (1a). $20 \mathrm{mg}$ of (PCP) $\mathrm{IrH}_{2}(0.034 \mathrm{mmol})$ was dissolved in $1 \mathrm{~mL}$ of $p$ xylene solution containing 1.5 equivalent of norbornene at room temperature. To the resulting solution was added $4.0 \square \mathrm{L}$ of aniline $(0.043 \mathrm{mmol})$; after stirring for ca. $2 \mathrm{~min}$, the red solution turned dark brown. Solvent was evacuated and the resulting solid was redissolved in and recrystallized from pentane; $22 \mathrm{mg}$ black crystals were obtained (95\% yield). ${ }^{31} \mathrm{P}$ NMR (121.4 MHz, $p$-xylene- $\left.d_{10}\right)$ : $\square 66.81$ (s). ${ }^{1} \mathrm{H}$ NMR (300 MHz, $p$-xylene$\left.d_{10}\right)$ : 7 7.16-6.91 (m, 5H, aniline H), $6.81\left(\mathrm{~d}, J_{\mathrm{HH}}=7.2 \mathrm{~Hz}, 2 \mathrm{H}, \mathrm{PCP} m-\mathrm{H}\right), 6.63\left(\mathrm{t}, J_{\mathrm{HH}}=\right.$ 
$7.2 \mathrm{~Hz}, 1 \mathrm{H}, \mathrm{PCP} p-\mathrm{H}), 4.90(\mathrm{~s}, 1 \mathrm{H}, \mathrm{N}-H), 3.16$ (d of vt, $J_{\mathrm{PH}}=3.6 \mathrm{~Hz}, J_{\mathrm{HH}}=17.1 \mathrm{~Hz}, 2 \mathrm{H}$, $\mathrm{CH}_{2}$ ), 3.08 (d of vt, $J_{\mathrm{PH}}=3.6 \mathrm{~Hz}, J_{\mathrm{HH}}=17.1 \mathrm{~Hz}, 2 \mathrm{H}, \mathrm{CH}_{2}$ ), $1.22\left(\mathrm{t}, J_{\mathrm{PH}}=6.45 \mathrm{~Hz}, 18 \mathrm{H}\right.$, $\left.\mathrm{C}\left(\mathrm{CH}_{3}\right)_{3}\right), 1.16\left(\mathrm{t}, J_{\mathrm{PH}}=6.30 \mathrm{~Hz}, 18 \mathrm{H}, \mathrm{C}\left(\mathrm{CH}_{3}\right)_{3}\right),-38.21\left(\mathrm{t}, J_{\mathrm{PH}}=12.6 \mathrm{~Hz}, 1 \mathrm{H}, \mathrm{Ir}-\mathrm{H}\right)$. Anal. Calc'd for $\mathrm{C}_{30} \mathrm{H}_{50} \mathrm{IrNP}_{2}$ : C, 53.09; H, 7.37; N, 2.06. Found: C, 52.79; H, 7.70; N, 1.90.

(PCP)IrH(NH $\left.\mathbf{N H}_{2}\right)$ (1b). Into a 5-mm screw-capped NMR tube was placed $30 \mathrm{mg}(0.047$ $\mathrm{mmol}$ ) of $\mathbf{3}$, followed by $0.3 \mathrm{~mL}$ of THF- $d_{8}$. The tube was cooled to $-78{ }^{\circ} \mathrm{C}$, and $13 \mathrm{mg}$ $(0.065 \mathrm{mmol})$ of $\mathrm{KN}\left(\mathrm{SiMe}_{3}\right)_{2}$ in $0.3 \mathrm{~mL}$ of THF- $d_{8}$ were added by syringe. The tube was inserted into a pre-cooled NMR spectrometer probe and was characterized at $-50{ }^{\circ} \mathrm{C}$. ${ }^{1} \mathrm{H}$ NMR (THF- $\left.d_{8},-50{ }^{\circ} \mathrm{C}\right) \square 6.71(\mathrm{~d}, J=6.2 \mathrm{~Hz}, 2 \mathrm{H}), 6.47(\mathrm{t}, J=6.2 \mathrm{~Hz}, 1 \mathrm{H}), 4.66(\mathrm{~s}, 2 \mathrm{H})$, $3.22\left(\mathrm{~d}\right.$ of vt, $\left.J_{\mathrm{PH}}=3.6 \mathrm{~Hz}, J_{\mathrm{HH}}=16.8 \mathrm{~Hz}, 2 \mathrm{H}\right), 3.10\left(\mathrm{~d}\right.$ of vt, $J_{\mathrm{PH}}=3.6 \mathrm{~Hz}, J_{\mathrm{HH}}=16.8 \mathrm{~Hz}$, $2 \mathrm{H}), 1.35-1.32(\mathrm{~m}, 36 \mathrm{H}),-26.66(\mathrm{t}, J=11.2 \mathrm{~Hz}, 1 \mathrm{H}) ;{ }^{13} \mathrm{C} \mathrm{NMR}\left(\mathrm{THF}-d_{8},-50{ }^{\circ} \mathrm{C}\right) \square$ $150.51(\mathrm{~d}, J=7.5 \mathrm{~Hz}), 148.02(\mathrm{t}, J=7.9 \mathrm{~Hz}), 120.68(\mathrm{t}, J=7.3 \mathrm{~Hz}), 119.98,38.21(\mathrm{t}, J=$ $15.4 \mathrm{~Hz}), 36.21(\mathrm{t}, J=9.9 \mathrm{~Hz}), 35.23(\mathrm{t}, J=10.8 \mathrm{~Hz}), 30.10,29.87 ;{ }^{31} \mathrm{P}$ NMR $\left(\mathrm{THF}-d_{8}\right.$, $\left.30{ }^{\circ} \mathrm{C}\right): \square 64.2(\mathrm{~d}, J=10.7 \mathrm{~Hz}) ;{ }^{15} \mathrm{~N}$ NMR of $\mathbf{1 b}-{ }^{15} \mathbf{N}\left(\mathrm{THF}-d_{8},-30{ }^{\circ} \mathrm{C}\right): \square 48.9(\mathrm{t}$ of $\mathrm{d}$ of $\mathrm{t}$, $\left.{ }^{1} J_{\mathrm{NH}}=70.9 \mathrm{~Hz},{ }^{2} J_{\mathrm{NH}}=8.0 \mathrm{~Hz},{ }^{2} J_{\mathrm{NP}}=4.0 \mathrm{~Hz}\right)$.

(PCP)Ir(NH $)$ (2). Into a $20 \mathrm{~mL}$ vial was placed $99 \mathrm{mg}$ of $3(0.16 \mathrm{mmol})$. This material was suspended in $8 \mathrm{~mL}$ of THF, and $33 \mathrm{mg}(0.165 \mathrm{mmol})$ of $\mathrm{KN}\left(\mathrm{SiMe}_{3}\right)_{2}$ in $2 \mathrm{~mL}$ of THF were added. The reaction was stirred at room temperature for $10 \mathrm{~min}$. After this time, the THF was evaporated under reduced pressure. The resulting orange film was dissolved in toluene, and the orange suspension was filtered through Celite quickly. The resulting solution was concentrated under vacuum. Slow addition of pentane and cooling at $-35{ }^{\circ} \mathrm{C}$ gave the title complex as orange needles in $32 \%$ yield. ${ }^{1} \mathrm{H}$ NMR $\left(\right.$ THF- $\left.d_{8}\right) \square 6.58(\mathrm{~d}, J=$ $7.1 \mathrm{~Hz}, 2 \mathrm{H}), 6.37$ (t, $J=7.1 \mathrm{~Hz}, 1 \mathrm{H}), 3.12(\mathrm{~s}, 3 \mathrm{H}), 2.82(\mathrm{~s}, 4 \mathrm{H}), 1.32(\mathrm{t}, J=6.2 \mathrm{~Hz}, 36 \mathrm{H})$; ${ }^{13} \mathrm{C}$ NMR $\left(\right.$ THF- $\left.d_{8}\right) \square 164.22,151.65(\mathrm{t}, J=11.4 \mathrm{~Hz}), 119.15(\mathrm{t}, J=8.5 \mathrm{~Hz}), 117.24$, $38.25(\mathrm{t}, J=13.7 \mathrm{~Hz}), 36.01(\mathrm{t}, J=8.4 \mathrm{~Hz}), 30.12 ;{ }^{31} \mathrm{P}$ NMR $\left(\mathrm{THF}-d_{8}\right): \square 68.4(\mathrm{~s}) ;{ }^{15} \mathrm{~N}$ NMR (THF- $\left.d_{8},-30{ }^{\circ} \mathrm{C}\right): \square-75.1(\mathrm{q}, J=67.2 \mathrm{~Hz})$; IR $\left(\mathrm{THF}, \mathrm{cm}^{-1}\right): 3488,3372,3345$, $3280\left(\mathrm{NH}_{3}\right)$.

(PCP)IrHCl( $\left.\mathbf{N H}_{3}\right)$ (3). Into a $20 \mathrm{~mL}$ scintillation vial equipped with a magnetic stir bar was placed $500 \mathrm{mg}(0.803 \mathrm{mmol})$ of (PCP)IrHCl. Into this vial was condensed $4 \mathrm{~mL}$ of liquid ammonia. Evaporation of the ammonia at room temperature generated $\mathbf{3}$ as a white powder in quantitative yield. ${ }^{1} \mathrm{H} \mathrm{NMR}\left(\mathrm{CD}_{2} \mathrm{Cl}_{2},-20{ }^{\circ} \mathrm{C}\right) \square 6.78(\mathrm{~d}, J=7.2 \mathrm{~Hz}, 2 \mathrm{H}), 6.57$ $(\mathrm{t}, J=7.2 \mathrm{~Hz}, 1 \mathrm{H}), 3.13(\mathrm{~d}, J=17.2 \mathrm{~Hz}, 2 \mathrm{H}), 2.91(\mathrm{~d}, J=17.2 \mathrm{~Hz}, 2 \mathrm{H}), 2.21(\mathrm{~s}, 3 \mathrm{H}), 1.33$ $(\mathrm{s}, 36 \mathrm{H}),-20.99(\mathrm{t}, J=16.4 \mathrm{~Hz}, 1 \mathrm{H}) ;{ }^{13} \mathrm{C} \mathrm{NMR}\left(\mathrm{CD}_{2} \mathrm{Cl}_{2}, 22{ }^{\circ} \mathrm{C}\right) \square 148.58(\mathrm{t}, J=7.0 \mathrm{~Hz})$, 145.68, 121.81, $120.74(\mathrm{t}, J=7.4 \mathrm{~Hz}), 37.93(\mathrm{t}, J=8.4 \mathrm{~Hz}), 36.83(\mathrm{t}, J=13.4 \mathrm{~Hz}), 36.08$ $(\mathrm{t}, J=12.0 \mathrm{~Hz}), 29.98,29.20 ;{ }^{31} \mathrm{P}$ NMR: $\left(\mathrm{CD}_{2} \mathrm{Cl}_{2},-30{ }^{\circ} \mathrm{C}\right) \square 46.4(\mathrm{~d}, J=14.6 \mathrm{~Hz})$. IR $\left(\mathrm{KBr}, \mathrm{cm}^{-1}\right): 2300(\mathrm{~s}, \mathrm{IrH}), 3395,3337,3265\left(\mathrm{NH}_{3}\right)$. Anal. Calc'd for $\mathrm{C}_{24} \mathrm{H}_{47} \mathrm{ClIrNP}_{2}$ : C, 45.09; H, 7.41; N, 2.19. Found: C, 45.16; H, 7.64; N, 2.46.

(PCP)IrHCl $\left({ }^{15} \mathbf{N H}_{3}\right)$ Into a $25 \mathrm{~mL}$ round-bottom flask was placed $220 \mathrm{mg}$ of $\mathbf{3}(0.353$ mmol). Ammonia ( $250 \mathrm{~mL}$ x 40.0 torr, $0.538 \mathrm{mmol}$ ) was added by vacuum transfer. The flask was warmed to $-42{ }^{\circ} \mathrm{C}$, and the color of the solid slowly changed from red to white. The flask was further warmed to room temperature, and $2 \mathrm{~mL}$ of toluene was added. Pentane $(8-10 \mathrm{~mL})$ was then added. The resulting suspension was filtered, and the solid 
was washed twice with pentane $(2 \mathrm{~mL})$. The product was dried in vacuo to give the title complex as a white powder in $91 \%$ yield. ${ }^{15} \mathrm{~N}$ NMR $\left(\mathrm{THF}-d_{8},-30{ }^{\circ} \mathrm{C}\right):-5-52.7$ (q of d, $J=$ $68.3,17.2 \mathrm{~Hz})$.

(PCP)Ir(H)(NHPh)(CO) (4a). $25 \mathrm{mg}(0.0369 \mathrm{mmol})$ of (PCP)IrH(NHPh) was dissolved in $600 \square \mathrm{L} p$-xylene. The solution was freeze-pump-thawed, and 800 torr of $\mathrm{CO}$ was immediately added. The dark brown solution quickly turned pale yellow. Solvent was evaporated under reduced pressure, and the resulting solid was redissolved in pentane and cooled at $-35{ }^{\circ} \mathrm{C}$; pale yellow crystals were obtained. ${ }^{31} \mathrm{P}$ NMR $(121.4 \mathrm{MHz}, p$-xylene$\left.d_{10}\right): \square 51.79(\mathrm{~s}) .{ }^{1} \mathrm{H}$ NMR (300 MHz, benzene- $\left.d_{6}\right)$ : $\square 7.27-6.89(\mathrm{~m}, 5 \mathrm{H}$, aniline $\mathrm{H}), 6.72$ $\left(\mathrm{d}, J_{\mathrm{HH}}=7.1 \mathrm{~Hz}, 2 \mathrm{H}, \mathrm{PCP} m-\mathrm{H}\right), 6.43\left(\mathrm{t}, J_{\mathrm{HH}}=7.1 \mathrm{~Hz}, 1 \mathrm{H}, \mathrm{PCP} p-\mathrm{H}\right), 3.02$ (d of vt, $\left.J_{\mathrm{PH}}=3.6 \mathrm{~Hz}, J_{\mathrm{HH}}=17.7 \mathrm{~Hz}, 2 \mathrm{H}, \mathrm{CH}_{2}\right), 2.95\left(\mathrm{~d}\right.$ of vt, $\left.J_{\mathrm{PH}}=4.2 \mathrm{~Hz}, J_{\mathrm{HH}}=16.5 \mathrm{~Hz}, 2 \mathrm{H}, \mathrm{CH}_{2}\right)$, $2.04(\mathrm{~s}, 1 \mathrm{H}, \mathrm{N}-H), 1.20\left(\mathrm{t}, J_{\mathrm{PH}}=6.9 \mathrm{~Hz}, 18 \mathrm{H}, \mathrm{C}\left(\mathrm{CH}_{3}\right)_{3}\right), 1.08\left(\mathrm{t}, J_{\mathrm{PH}}=6.6 \mathrm{~Hz}, 18 \mathrm{H}\right.$, $\left.\mathrm{C}\left(\mathrm{CH}_{3}\right)_{3}\right),-7.73\left(\mathrm{td}, J_{\mathrm{PH}}=15.6 \mathrm{~Hz}, J_{\mathrm{HH}}=1.9 \mathrm{~Hz}, 1 \mathrm{H}, \mathrm{Ir}-H\right)$. IR (pentane): $\mathrm{CoO}_{\mathrm{co}} 1928.4 \mathrm{~cm}^{-1}$. Anal. Calc'd for $\mathrm{C}_{31} \mathrm{H}_{50} \mathrm{OIrNP}_{2}$ : C, 52.67; H, 7.08; N, 1.98. Found: C, 52.25; H, 7.33; N, 1.60 .

(PCP)IrH( $\left.\mathbf{N H}_{2}\right)\left(\mathbf{C N}^{t} \mathbf{B u}\right)$ (4b). Into a $25 \mathrm{~mL}$ round-bottom flask equipped with a magnetic stir bar was placed $235 \mathrm{mg}$ of $\mathbf{3}(0.368 \mathrm{mmol})$. This material was suspended in $8 \mathrm{~mL}$ of THF and was cooled to $-78{ }^{\circ} \mathrm{C}$. A solution of $100 \mathrm{mg}(0.500 \mathrm{mmol}, 1.4$ equiv) of $\mathrm{KN}\left(\mathrm{SiMe}_{3}\right)_{2}$ in $3 \mathrm{~mL}$ of $\mathrm{THF}$ was added to the solution slowly via syringe. The reaction was stirred at $-78{ }^{\circ} \mathrm{C}$ for $10 \mathrm{~min}$, after which time the solution was homogeneous and orange. To this solution was added tert-butyl isocyanide (50 $\square \mathrm{L}, 0.443 \mathrm{mmol}, 1.2$ equiv) via syringe. The solution became clear immediately and was warmed to room temperature slowly. The THF was evaporated under reduced pressure. The resulting pale orange solid was extracted with pentane, and the pale orange suspension was filtered through Celite quickly. The pentane was evaporated under vacuum, giving the title complex as a yellow solid in $56 \%$ yield. ${ }^{1} \mathrm{H}$ NMR $\left(\mathrm{THF}-d_{8},-15{ }^{\circ} \mathrm{C}\right) \square 6.72(\mathrm{~d}, J=7.4 \mathrm{~Hz}$, $2 \mathrm{H}), 6.49(\mathrm{t}, J=7.4 \mathrm{~Hz}, 1 \mathrm{H}), 3.22-3.19(\mathrm{~m}, 4 \mathrm{H}), 1.44(\mathrm{t}, J=6.2 \mathrm{~Hz}, 18 \mathrm{H}), 1.28-1.24(\mathrm{~m}$, $27 \mathrm{H}),-2.39(\mathrm{~s}, 2 \mathrm{H}),-10.82(\mathrm{t}, J=18.0 \mathrm{~Hz}, 1 \mathrm{H}) ;{ }^{13} \mathrm{C}$ NMR $\left(\mathrm{THF}-d_{8},-15{ }^{\circ} \mathrm{C}\right) \square 153.37$, $148.47(\mathrm{t}, J=6.4 \mathrm{~Hz}), 139.37,121.70,119.93(\mathrm{t}, J=6.9 \mathrm{~Hz}), 56.28,40.97(\mathrm{t}, J=14.0$ $\mathrm{Hz}), 36.80(\mathrm{t}, J=8.6 \mathrm{~Hz}), 36.66(\mathrm{t}, J=12.2 \mathrm{~Hz}), 30.79,30.54,29.83 ;{ }^{31} \mathrm{P}$ NMR $\left(\mathrm{THF}-d_{8}\right.$, $\left.15{ }^{\circ} \mathrm{C}\right)$ : $\square 50.5(\mathrm{~s})$; IR $\left(\mathrm{KBr}, \mathrm{cm}^{-1}\right): 2099,2173(\mathrm{CN}), 3239\left(\mathrm{NH}_{2}\right)$. Anal. Calc'd for $\mathrm{C}_{29} \mathrm{H}_{55} \mathrm{IrN}_{2} \mathrm{P}_{2}$ : C, 50.78; H, 8.08; N, 4.08. Found: C, 51.01; H, 8.21; N, 3.87.

(PCP)Ir(CN'Bu) (5b). Into a $20 \mathrm{~mL}$ vial was placed $250 \mathrm{mg}$ of $\mathbf{3}(0.391 \mathrm{mmol})$. This material was suspended in $8 \mathrm{~mL}$ of THF, and a solution of $93 \mathrm{mg}(0.465 \mathrm{mmol})$ of $\mathrm{KN}\left(\mathrm{SiMe}_{3}\right)_{2}$ in $2 \mathrm{~mL}$ of $\mathrm{THF}$ was added at room temperature. The reaction was stirred at room temperature for $10 \mathrm{~min}$. tert-Butyl isocyanide (50 [LL, $0.443 \mathrm{mmol}$ ) was added via syringe. The THF was evaporated under reduced pressure, and the resulting red solid was dissolved in toluene. The red suspension was filtered through Celite, and the resulting solution was concentrated under vacuum. Slow addition of pentane and cooling at $-35{ }^{\circ} \mathrm{C}$ gave the title complex as red crystals in $60 \%$ yield. ${ }^{1} \mathrm{H}$ NMR (THF- $\left.d_{8}\right) \square 6.93$ $(\mathrm{d}, J=7.2 \mathrm{~Hz}, 2 \mathrm{H}), 6.63(\mathrm{t}, J=7.2 \mathrm{~Hz}, 1 \mathrm{H}), 3.37(\mathrm{vt}, J=3.6 \mathrm{~Hz}, 4 \mathrm{H}), 1.42(\mathrm{~s}, 9 \mathrm{H}), 1.36$ $(\mathrm{t}, J=6.0 \mathrm{~Hz}, 36 \mathrm{H}) ;{ }^{13} \mathrm{C}$ NMR $\left(\mathrm{THF}_{-} \mathrm{d}_{8}\right) \square 182.18(\mathrm{t}, J=4.1 \mathrm{~Hz}), 161.57(\mathrm{t}, J=8.8 \mathrm{~Hz})$, $155.28(\mathrm{t}, J=11.8 \mathrm{~Hz}), 123.46,119.52(\mathrm{t}, J=8.3 \mathrm{~Hz}), 54.97,40.23(\mathrm{t}, J=14.2 \mathrm{~Hz})$, 
$36.59(\mathrm{t}, J=9.9 \mathrm{~Hz}), 31.18,30.29(\mathrm{t}, J=3.4 \mathrm{~Hz}) ;{ }^{31} \mathrm{P}$ NMR $\left(\mathrm{THF}-\mathrm{d}_{8}\right)$ : $\square 78.6(\mathrm{~s}) . \mathrm{IR}(\mathrm{KBr}$, $\mathrm{cm}^{-1}$ ): 2013 (s, CN). Anal. Calc'd for $\mathrm{C}_{29} \mathrm{H}_{52} \mathrm{IrNP}_{2}$ : C, 52.07; H, 7.84; N, 2.09. Found: C, $52.25 ; \mathrm{H}, 8.05 ; \mathrm{N}, 2.04$.

Reaction of 1a with 4-(trifluoromethyl)aniline. To a solution of (PCP) $\operatorname{IrH}(\mathrm{NHPh})(10$ $\mathrm{mg}, 0.0147 \mathrm{mmol}$, in $0.5 \mathrm{~mL} p$-xylene) was added $3.0 \mathrm{QL}$ of 4-(trifluoromethyl)aniline $(0.024 \mathrm{mmol})$. The dark brown solution turned black within a minute, and formation of (PCP) $\mathrm{IrH}\left(p-\mathrm{NHC}_{6} \mathrm{H}_{4} \mathrm{CF}_{3}\right)$ was subsequently observed (95\% yield) by ${ }^{1} \mathrm{H}$ and ${ }^{31} \mathrm{P} \mathrm{NMR}$. The spectral data for (PCP) $\mathrm{IrH}\left(p-\mathrm{NHC}_{6} \mathrm{H}_{4} \mathrm{CF}_{3}\right)$ was confirmed by independent synthesis.

(PCP)IrH( $\left.\boldsymbol{p}-\mathrm{NHC}_{\mathbf{6}} \mathbf{H}_{\mathbf{4}} \mathbf{C F}_{3}\right)$. At room temperature, $20 \mathrm{mg}(0.0304 \mathrm{mmol})$ of (PCP)IrH $\mathrm{I}_{2}$ was dissolved in $1 \mathrm{~mL}$ of $p$-xylene containing 1.5 equivalent of norbornene. To the resulting solution was added 5.0 $\square \mathrm{L}$ of 4 -(trifluoromethyl)aniline $(0.037 \mathrm{mmol})$; after stirring for ca. $2 \mathrm{~min}$, the red solution turned black. The solvent was evaporated under reduced pressure to leave $22 \mathrm{mg}(97 \%)$ of a black powder. ${ }^{31} \mathrm{P}$ NMR $(121.4 \mathrm{MHz}, p$ xylene- $\left.d_{10}\right)$ : $\square 67.09(\mathrm{~s}) .{ }^{1} \mathrm{H}$ NMR $\left(300 \mathrm{MHz}, p\right.$-xylene- $\left.d_{10}\right): \square 7.39\left(\mathrm{~d}, J_{\mathrm{HH}}=8.4 \mathrm{~Hz}, 2 \mathrm{H}\right.$, $m-\mathrm{H}), 7.07\left(\mathrm{~d}, J_{\mathrm{HH}}=7.5 \mathrm{~Hz}, 2 \mathrm{H}, \mathrm{PCP} m-\mathrm{H}\right), 6.94\left(\mathrm{t}, J_{\mathrm{HH}}=7.5 \mathrm{~Hz}, 1 \mathrm{H}, \mathrm{PCP} p-\mathrm{H}\right), 6.42(\mathrm{~d}$, $\left.J_{\mathrm{HH}}=8.4 \mathrm{~Hz}, 2 \mathrm{H}, o-\mathrm{H}\right), 3.87(\mathrm{~s}, 1 \mathrm{H}, \mathrm{N}-H), 3.16\left(\mathrm{~d}\right.$ of vt, $J_{\mathrm{PH}}=3.9 \mathrm{~Hz}, J_{\mathrm{HH}}=17.4 \mathrm{~Hz}, 2 \mathrm{H}$, $\mathrm{CH}_{2}$ ), 3.03 (d of vt, $J_{\mathrm{PH}}=3.9 \mathrm{~Hz}, J_{\mathrm{HH}}=17.4 \mathrm{~Hz}, 2 \mathrm{H}, \mathrm{CH}_{2}$ ), $1.11\left(\mathrm{t}, J_{\mathrm{PH}}=6.6 \mathrm{~Hz}, 18 \mathrm{H}\right.$, $\left.\mathrm{C}\left(\mathrm{CH}_{3}\right)_{3}\right), 1.07,\left(\mathrm{t}, J_{\mathrm{PH}}=6.3 \mathrm{~Hz}, 18 \mathrm{H}, \mathrm{C}\left(\mathrm{CH}_{3}\right)_{3}\right),-43.31\left(\mathrm{t}, J_{\mathrm{PH}}=13.2 \mathrm{~Hz}, 1 \mathrm{H}, \mathrm{Ir}-H\right)$.

Reaction of (PCP) $\mathrm{IrH}_{2}$ with norbornene and ammonia. Into a small vial containing a stir bar were placed $10 \mathrm{mg}(0.017 \mathrm{mmol})(\mathrm{PCP}) \mathrm{IrH}_{2}$ and $7 \mathrm{mg}(0.07 \mathrm{mmol})$ norbornene. Pentane $(0.6 \mathrm{~mL})$ was added, and the solution was stirred for $30 \mathrm{~min}$. The solution was transferred to an NMR tube equipped with a Teflon stopcock. $\mathrm{NH}_{3}(61.0 \mathrm{~mL}$ x 20 torr, $0.066 \mathrm{mmol}$ ) was added by vacuum transfer, and the tube was closed. An orange precipitate formed within $10 \mathrm{~min}$ at room temperature. The pentane was evaporated under vacuum. To this solid was added a stock solution of dodecahydrotriphenlene in THF- $d_{8}$. ${ }^{1} \mathrm{H}$ NMR spectroscopy of this complex showed that the ammonia complex was formed in $29 \%$ yield.

Reaction of (PCP)IrH(NHPh) with ammonia. (PCP) $\operatorname{IrH}(\mathrm{NHPh})$ (1a) $(11 \mathrm{mg}, 0.017$ mmol) was dissolved in $0.6 \mathrm{~mL}$ of $p$-xylene, and this solution was loaded into an NMR tube equipped with a Teflon stopcock. $\mathrm{NH}_{3}(61.0 \mathrm{~mL}$ x 20 torr, $0.066 \mathrm{mmol})$ was added by vacuum transfer, and the tube was sealed. The color of the solution quickly changed from dark brown to orange. The $p$-xylene was evaporated under vacuum. To this solid was added a stock solution of dodecahydrotriphenlene in THF- $d_{8} .{ }^{1} \mathrm{H}$ NMR spectroscopy of this complex showed that the ammonia complex was formed in $30 \%$ yield.

Reductive elimination of ammonia from $\mathbf{4 b}$. Complex $\mathbf{4 b}(10 \mathrm{mg}, 0.015 \mathrm{mmol})$, along with dodecahydrotriphenylene as internal standard (ca. $2 \mathrm{mg}$ ) was dissolved in $0.6 \mathrm{~mL}$ of THF- $d_{8}$, and this solution was loaded into a 5-mm, screw-capped NMR tube. A ${ }^{1} \mathrm{H} \mathrm{NMR}$ spectrum was obtained within $5 \mathrm{~min}$. The tube was allowed to stand at room temperature for $12 \mathrm{~h}$, after which time the color of the solution changed from light yellow to red. A second ${ }^{1} \mathrm{H}$ NMR spectrum showed that complex $\mathbf{5 b}$ was formed in $90 \%$ yield. 
Reductive elimination of aniline from 4a. Complex $4 \mathbf{a}(10 \mathrm{mg}, 0.015 \mathrm{mmol})$ was dissolved in $0.6 \mathrm{~mL}$ of $p$-xylene- $d_{10}$ and the solution was loaded into a 5-mm, screwcapped (J. Young) NMR tube. The tube was then heated at $90^{\circ} \mathrm{C}$ for $4 \mathrm{~h}$ and periodically monitored (30 min intervals) by ${ }^{31} \mathrm{P}$ NMR. The data was plotted according to first-order kinetics and fit well $\left(\mathrm{r}^{2}=0.98\right)$ to a rate constant of $0.15 \mathrm{~h}^{-1}$.

Measurement of the equilibrium constant for the interconversion of $1 \mathrm{a}$ and (PCP)IrHPh. Complex 1a (12 mg, $0.018 \mathrm{mmol})$ was dissolved in $0.6 \mathrm{ml}$ of benzene, and the solution was loaded into a $5-\mathrm{mm}$ screw-capped NMR tube. The tube was allowed to stand at room temperature. A ${ }^{31} \mathrm{P}$ NMR spectrum was obtained after $1 \mathrm{~h}$, and this spectrum showed that $74 \%$ of 1a has been converted to (PCP)IrHPh. After $4 \mathrm{~h}$, a second ${ }^{31}$ P NMR spectrum was identical to the first spectrum, indicating that equilibrium had been established.

Low-temperature reaction of "(PCP)Ir" with aniline (reference 16). Into a 5-mm extended NMR tube was placed $10 \mathrm{mg}$ of (PCP) $\mathrm{IrH}_{2}(0.017 \mathrm{mmol})$, followed by $0.3 \mathrm{~mL}$ of a mesitylene- $d_{12}$ solution containing 2 equiv of norbornene at room temperature. The tube was cooled to $-78{ }^{\circ} \mathrm{C}$ and $4.0 \square \square$ of aniline $(0.043 \mathrm{mmol})$ in $0.2 \mathrm{~mL}$ of mesitylene- $d_{12}$ was slowly added by syringe. The tube was sealed and then inserted into a pre-cooled NMR spectrometer probe and allowed to warm to $-40{ }^{\circ} \mathrm{C}$. After $30 \mathrm{~min}$, the starting material was converted (90\% NMR yield) to a new species: ${ }^{31} \mathrm{P}$ NMR (mesitylene- $d_{12},-40$ ${ }^{\circ} \mathrm{C}$ ): $\mathrm{C54.26} ;{ }^{1} \mathrm{H}$ NMR (mesitylene- $d_{12},-40{ }^{\circ} \mathrm{C}$ ): -25.16 (t, $J=16.8 \mathrm{~Hz}$ ). Other ${ }^{1} \mathrm{H}$ NMR resonance of the product were not assigned due to overlap with signals from excess of norbornene and norbornane. Upon slowly warming the solution above $-30{ }^{\circ} \mathrm{C}$, this species was completely converted to $\mathbf{1 a}$.

Following the same procedure, $10 \mathrm{mg}$ of $(\mathrm{PCP}) \mathrm{IrH}_{2}(0.017 \mathrm{mmol})$ was allowed to react with $4.0 \square$ of aniline-2,3,4,5,6- $d_{5}(0.043 \mathrm{mmol})$ at $-40^{\circ} \mathrm{C}$ in mesitylene- $d_{12}$. After 30 $\mathrm{min}$, the starting material was converted to the new species. ${ }^{31} \mathrm{P}$ NMR (mesitylene- $d_{12},-40$ ${ }^{\circ} \mathrm{C}$ ): 7 54.26; no hydride peak observed in the ${ }^{1} \mathrm{H}$ NMR spectrum at $-40{ }^{\circ} \mathrm{C}$. Upon warming above $-30{ }^{\circ} \mathrm{C}$, the reaction intermediate converted to $(\mathrm{PCP}) \operatorname{Ir}(\mathrm{H})\left[\mathrm{NH}\left(\mathrm{Ph}-d_{5}\right)\right]$. 


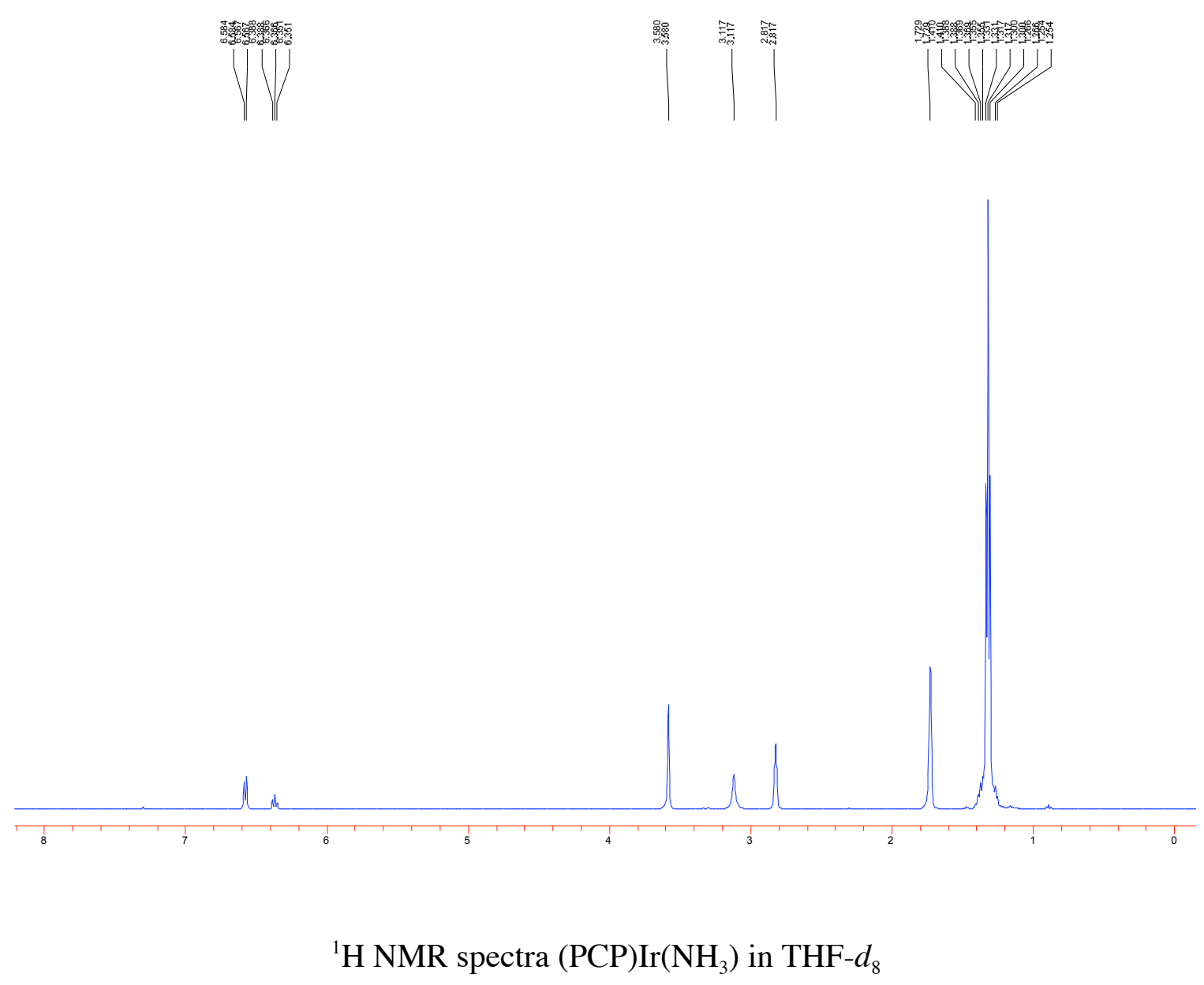




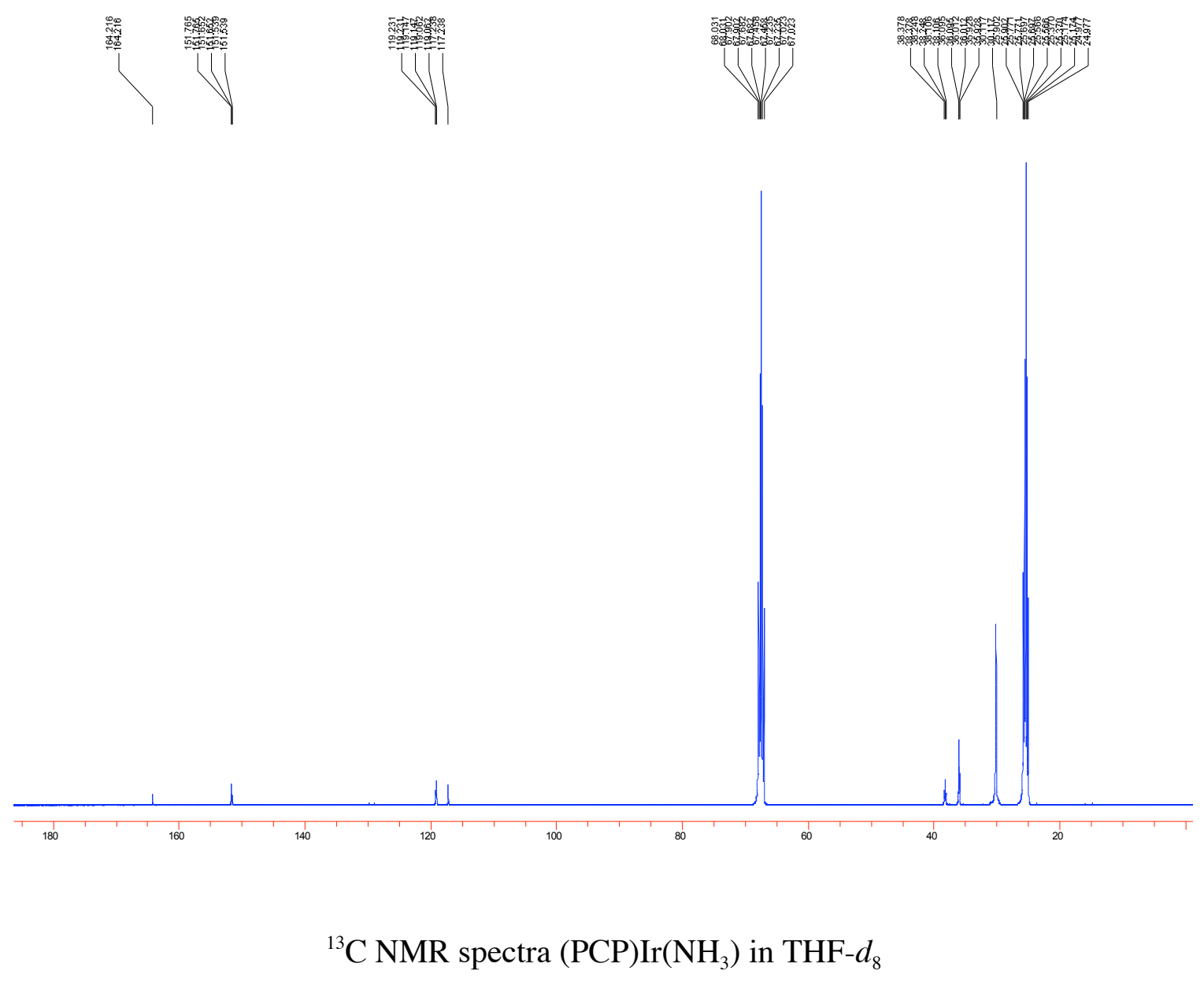

\section{Reference for supporting information:}

1)Gupta, M.; Hagen, C.; Kaska, W. C.; Cramer, R. E.; Jensen, C. M. J. Am. Chem. Soc. 1997, 119, 840-841.

2)Moulton, C. J.; Shaw, B. L. J. Chem. Soc., Dalton Trans. 1976, 1020-1024. 